\title{
Plans to dilute and dispose 48.2 MT of U.S. surplus plutonium at the Waste Isolation Pilot Plant: changing the nature of WIPP
}

\author{
ANNIE B. KERSTING ${ }^{1}$ AND ANDREW ORRELL ${ }^{2}$ \\ ${ }^{1}$ Lawrence Livermore National Lab \\ ${ }^{2}$ Idaho National Laboratory \\ Presenting Author: kersting1@1lnl.gov
}

The United States has declared over 60 metric tons (MT) of weapons-grade plutonium as surplus to defense needs, and that requires adequate disposition to address non-proliferation goals. DOE-NNSA has proposed to dilute and dispose up to 48.2 MT of this surplus plutonium in the Waste Isolation Pilot Plant (WIPP), New Mexico, USA. In 2016, Congress requested the National Academies of Science (NAS) assess the viability of DOE's plan that is expected to take about 30 years and cost approximately $\$ 18$ billion. The surplus plutonium inventory is derived from material previously used in research, scraps and residues managed as transuranic waste, non-pit metal, plutonium oxide, and plutonium pits. WIPP is currently the nation's only operational geologic repository licensed for deep geologic disposal of transuranic waste, with a legislated capacity of 175,564 cubic meters. The repository is located $2160 \mathrm{ft}(658 \mathrm{~m})$ below ground in the Permian Basin salt beds of southeast New Mexico, which plastically deforms around the waste and act as the primary containment barrier. WIPP post-closure performance analysis has shown the probability of release to the environment is extremely low over the $10 \mathrm{~K}$ year regulatory period. The NAS committee reached a consensus that the process of dilute and dispose is technically viable, but that the increased amount of disposed plutonium will result in substantial changes to the overall physical, radiological, and chemical composition of the emplaced waste. In the NAS report ${ }^{1}$ they state that "no previous waste stream has affected the technical measures of WIPP performance at the same levels" and recommend that while the WIPP repository is assumed to maintain regulatory compliance, DOE should implement a new comprehensive programmatic environmental impact statement to fully assess the impacts of the total surplus plutonium inventory intended for dilution and disposal at WIPP. This talk will focus on the current process for the dilute and dispose of surplus plutonium and the changing chemical and radiological nature of WIPP.

${ }^{1}$ National Academies of Sciences, Engineering, and Medicine 2020. Review of the Department of Energy's Plans for Disposal of Surplus Plutonium in the Waste Isolation Pilot Plant. Washington, DC: The National Academies Press. https://doi.org/10.17226/25593. 